\title{
Evaluation and Comparison of Root Resorption Resulting from Traditional and Bone-borne Rapid Maxillary Expansion Appliances Using Cone-beam Computed Tomography
}

\author{
Konik Işınlı Bilgisayarlı Tomografi Kullanılarak Geleneksel ve \\ Kemik Destekli Hızlı Üst Çene Genişletme Yöntemlerinin Kök \\ Rezorpsiyonuna Etkisinin Değerlendirilmesi ve Karşılaştırılması
}

(1) Mehmet Akin ${ }^{1}$, (D Onur Öztürk ${ }^{2}$

${ }^{1}$ Alanya Alaaddin Keykubat University Faculty of Dentistry, Department of Orthodontics, Alanya, Turkey

${ }^{2}$ Private Practice, Bursa, Turkey

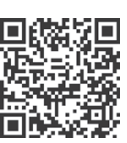

Keywords

$\mathrm{CBCT}$, rapid maxillary expansion, root resorption

Anahtar Kelimeler

KIBT, hızlı üst çene genişletme, kök rezorpsiyonu

Received/Geliş Tarihi : 05.01.2021

Accepted/Kabul Tarihi : 01.02.2021

doi:10.4274/meandros.galenos.2021.47135

Address for Correspondence/Yazışma Adresi: Mehmet Akın Assoc. Prof. Dr.,

Alanya Alaaddin Keykubat University Faculty of Dentistry, Department of Orthodontics, Alanya, Turkey

Phone : +90 5326860899

E-mail :drmehmetakin07@gmail.com

ORCID ID: orcid.org/0000-0003-0776-7653

(C) Meandros Medical and Dental Journal, Published by Galenos Publishing House.

This is article distributed under the terms of the

Creative Commons Attribution NonCommercial 4.0

International Licence (CC BY-NC 4.0).

\section{Abstract}

Objective: This study aimed to evaluate the resorptions of the roots of the maxillary posterior teeth after traditional rapid maxillary expansion (TRME) therapy and boneborne rapid maxillary expansion (BBRME) appliances and to compare the findings obtained using the two appliances.

Materials and Methods: The study enrolled 40 patients treated at the orthodontics clinic. These patients were divided into the TRME group (13.4 \pm 1.2 years old, $n=20)$ and BBRME group (13.2 \pm 1.3 years old, $n=20)$ according to the appliance used. Conebeam computed tomography images taken before the treatment (TO) and after a 3-month retention period ( $\mathrm{T} 1$ ) was transferred to an image-processing software. Volumetric measurements of the teeth were made after the segmentation procedure, and volumetric changes before and after treatments were analysed statistically. Paired-sample t-test was used for the intra-group comparison, and independentsample t-test was used for the inter-group comparison.

Results: In both groups, the amount of resorption in all teeth that occurred between T0 and T1, was statistically significant $(p<0.001)$. In the TRME group, the highest resorption was measured in the $1^{\text {st }}$ molars $\left(79.65 \mathrm{~mm}^{3}\right)$, and the lowest resorption was measured in the $2^{\text {nd }}$ premolars $\left(33.38 \mathrm{~mm}^{3}\right)$. In the BBRME group, the highest resorption was measured in the $1^{\text {st }}$ molars $\left(46.74 \mathrm{~mm}^{3}\right)$, and the lowest resorption was measured in the $1^{\text {st }}$ premolars $\left(21.61 \mathrm{~mm}^{3}\right)$. In the comparison of root resorptions that occurred between T0 and T1 in the two groups, analysis results showed that the BBRME group demonstrated lower root resorption $(p<0.05)$.

Conclusion: The results suggest that BBRME causes less root resorption than TRME. 
Öz

Amaç: Bu çalışmanın amacı, geleneksel hızlı üst çene genişletme (GHÜÇG) ve kemik destekli hızlı üst çene genişletme (KDHÜÇG) yöntemlerinin arka üst diş köklerinin rezorpsiyonuna etkisini değerlendirmek ve iki cihaz kullanılarak elde edilen bulguları karşılaştırmaktır. Gereç ve Yöntemler: Çalışma ortodonti kliniğinde tedavi gören 40 hasta ile yapılmıştır. Çalışma iki grup halinde tasarlanmıştır. Birinci

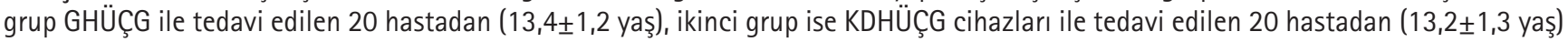
oluştu. Hastalardan tedavi öncesi (T0) ve 3 aylık tutma (T1) sonrası alınan konik ışınlı bilgisayarlı tomografi kayıtları programa aktarıldı. Segmentasyon işleminden sonra dişlerin hacimsel ölçümleri yapıldı ve tedavi öncesi ve sonrası hacimsel değişimler istatistiksel olarak analiz edildi. Grup içi karşılaştırmada bağımlı örnek t-testi, gruplar arası karşılaştırmada ise bağımsız-örneklem t-testi kullanıldı.

Bulgular: Her iki grupta da T0-T1 arasında meydana gelen tüm dişlerde rezorpsiyon miktarı istatistiksel olarak anlamlı bulundu $(p<0,001)$. GHÜÇG grubunda en yüksek rezorpsiyon 1. büyük azılarda $\left(79,65 \mathrm{~mm}^{3}\right)$, son olarak en düşük rezorpsiyon 2 . küçük azılarda $\left(33,38 \mathrm{~mm}^{3}\right)$ ölçüldü. KDHÜÇG grubunda en yüksek rezorpsiyon 1. büyük azılarda $\left(46,74 \mathrm{~mm}^{3}\right)$, son olarak en düşük rezorpsiyon 1 . küçük azılarda $\left(21,61 \mathrm{~mm}^{3}\right)$ ölçüldü. T0 ile T1 arasında meydana gelen kök rezorpsiyonunun iki grupta karşılaştırılmasında, statik olarak sonuçlar KDHÜÇG grubunun daha düşük kök rezorpsiyonu meydana getirdiğini göstermiştir $(\mathrm{p}<0.05)$.

Sonuç: Kemik destekli hızlı üst çene genişletmenin, geleneksel hızlı üst çene genişletmeye göre daha az kök rezorpsiyonuna neden olduğu kanıtlanmıştır.

\section{Introduction}

Rapid maxillary expansion (RME), used frequently in cases of maxillary transversal constriction, was first introduced by Emerson C. Angell in 1860 (1). Interest in RME increased in the late 1940s when Graber claimed that RME was necessary for the treatment of patients with cleft lip and palate (2). Later, this method gained popularity following Haas' studies (3). Numerous different RME appliances have been designed up till now. The studies and resulting advancements in RME tecniques have enabled clinician to adopt various treatment strategies by choosing the most appropriate appliance type for the case (4-7).

Forces transmitted by RME exert, orthopedic effects occur on maxilla that cause maxillary expansion by sutural opening (8). Severe forces required for this sutural opening may cause side effects on the covered tooth such as resorption $(9,10)$, fenestration (11) and dental tipping $(2,12)$. Bone-borne rapid maxillary expansion (BBRME) appliances were designed with the developments in the skeletal anchorage in order to prevent or at least to decrease these disadvantages. Force is directly transmitted to the maxilla with the help of anchorage units in BBRME (13). Different types were applied according to the miniscrew number and location $(6,7,14)$. Hybrid expander, designed by Akin et al. (14), is supported by acrylic pads and two miniscrews placed on the palatal bone between the $2^{\text {nd }}$ premolar and the $1^{\text {st }}$ molar.

Two dimensional radiographic methods are inadequate for the detailed measurements of root resorption owing to magnification, distortion and superimpositions (15-17). Three dimensional
(3D) screening methods enables more reliable measurements by eliminating these disadvantages (15). Among 3D techniques, micro computed tomography (CT) and SEM are used in vitro, therefore the studied teeth should be extracted teeth (18). Cone-beam CT (СBCT) is preferred for the in vivo studies $(7,10,17)$.

The aim of this study is to measure root resorptions of $1^{\text {st }}$ molar, $1^{\text {st }}$ premolar and $2^{\text {nd }}$ premolar teeth after the therapy with traditional rapid maxillary expansion (TRME) and BBRME appliances, and to compare these findings between two appliances. The null hypothesis of our study is, between TRME and BBRME there would not be any difference in the amount of root resorption after the retention period.

\section{Materials and Methods}

Patient records of this retrospective study were collected after obtaining the Selçuk University, Faculty of Dentistry Ethics Committee Approval in Non-Invasive Clinical Trials (protocol no: 2015/01, date: 08.10 .2015$)$. Forty patients (20 girls, 20 boys) who had been treated by RME in Selçuk University, Department of Orthodontics, were included in the study.

The sample size for the study was determined by using G*Power analyses (Ver.3.0.10 Franz Faul Universitat, Kiel, Germany). At 0.45 effect size and 0.05 significance level in two group and repeated measurements 40 patients had given $89.4 \%$ power. They were divided into two groups, each consisting of 20 individuals. The inclusion criteria are in Table 1. 
The first group consisted of 8 girls and 12 boys with a mean age, $13.4 \pm 0.1$ years; range, $12.2-14$. 8 years. All patients and their parents were informed about the research and signed informed consent forms. These patients were treated with modified acrylic cap splint (Figure 1) RME appliance and had CBCT records taken at the beginning of the treatment and after 3 months retention period.

The second group consisted of 12 girls and 8 boys with a mean age, $13.2 \pm 0.1$ years; range, 11.8-14.5 years. These patients were treated with the Hybrid expander (Figure 2) for BBRME appliance and had $\mathrm{CBCT}$ records taken at the beginning of the treatment and after a 3 month retention period.

All tomographic records were taken by the same machine (Kodak, CS 9300, Carestream Health Inc,

\begin{tabular}{|l|}
\hline Table 1. Inclusion and exclusion criteria \\
\hline The following are criteria for the inclusion of patients \\
\hline Who had bilateral contsriction on the maxillary basal bone. \\
\hline Who achieved 7-9 mm sutural expansion after the treatment. \\
\hline $\begin{array}{l}\text { Who did not have any orthodontic treatment before the RME } \\
\text { therapy. }\end{array}$ \\
\hline Who used the RME appliance properly. \\
\hline Who were in the permanent dentition. \\
\hline Who had CBCT record preexpansion and post retention. \\
\hline Who are 12-15 years old. \\
\hline The following are criteria for the exclusion of patients \\
\hline $\begin{array}{l}\text { Who had apical lesions, cyst and anomalies on the covered } \\
\text { teeth. }\end{array}$ \\
\hline Whose teeth's root closings were not completed. \\
\hline Whose teeth were missing. \\
\hline Who had coronal restorations on the covered teeth. \\
\hline Who did not have sufficient CBCT records. \\
\hline $\begin{array}{l}\text { CBCT: Cone-beam computed tomography, RME: Rapid maxillary } \\
\text { expansion }\end{array}$ \\
\hline
\end{tabular}

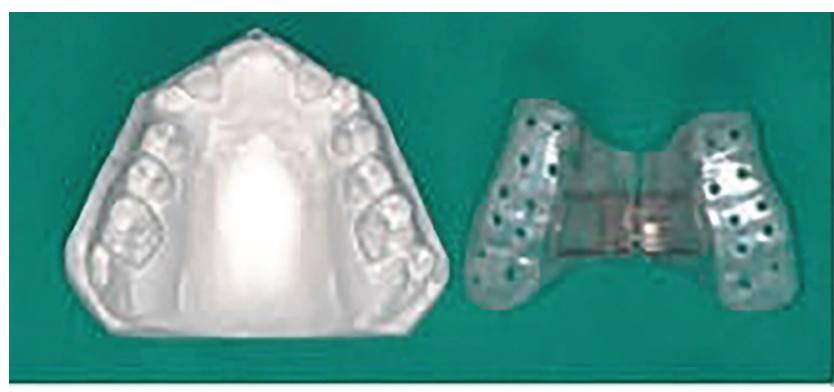

Figure 1. Modified acrylic cap splint rapid maxillary expansion appliance
Rochester, NY) and at the following settings: $8.0 \mathrm{~mA}$ and $70 \mathrm{kV}$ for 6.15 seconds, $0.18 \mathrm{~mm}$ axial slice thickness. CBCT records of the patients were configurated as $3 \mathrm{D}$ after being transferred to Mimics Innovation Suite (Version 10.01 Materialise, Leuve, Belgium). First, the density settings were applied for the transferred images. The most appropriate density ranges for the segmentation of the teeth were decided for each patient. CBCT records, taken in the beginning of the treatment and 3 months after the retention period, of each patient were segmented in the same density setting. On these 3D images, permanent first molars and first and second premolars were segmented.

After the segmentation of the $1^{\text {st }}$ premolar, $2^{\text {nd }}$ premolar and the $1^{\text {st }}$ molar teeth, they were isolated by splitting the surrounding structures (Figure 3 ). The volumetric measurements of the isolated teeth were made and changes occuring at the beginning and after the retention were recorded (Figure 4). Percentage changes of the teeth volumes were also recorded by calculating the ratio as T0-T1 (change in volume) /TO (initial volume).

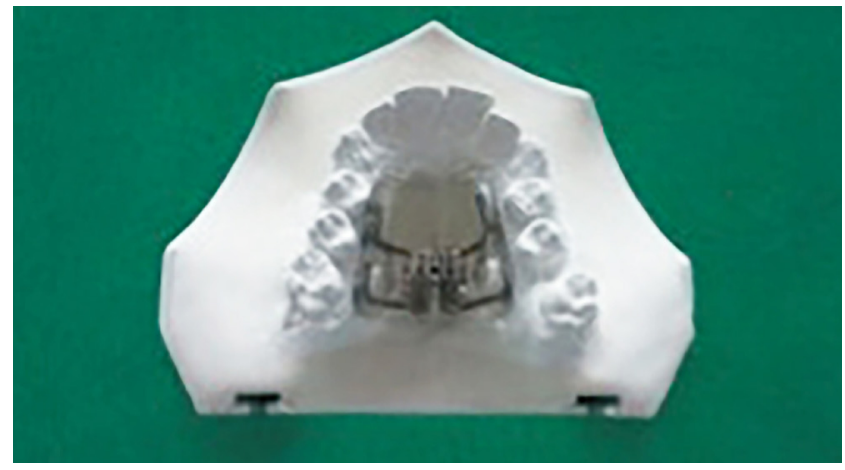

Figure 2. Hybrid expander rapid maxillary expansion appliance

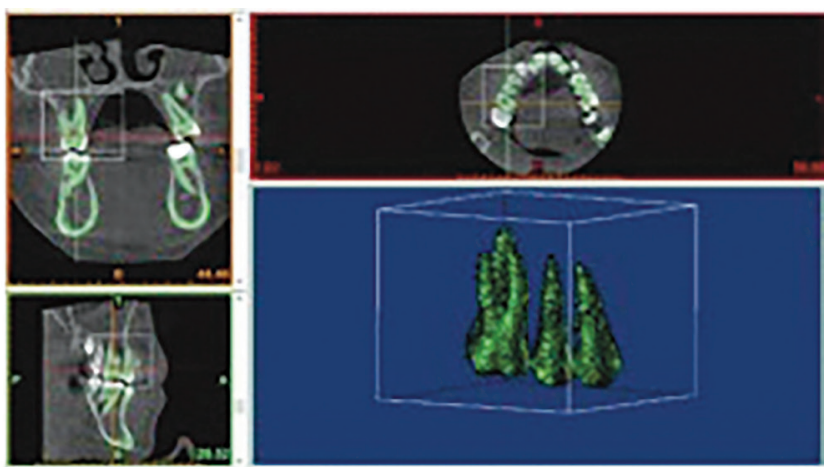

Figure 3. After the segmentation of $1^{\text {st }}$ premolar, $2^{\text {nd }}$ premolar ve $1^{\text {st }}$ molar teeth, teeth were isolated by splitting the surrounding structures 


\section{Statistical Analysis}

Normality of the collected data was tested by Shapiro-Wilk normality test, and it was found that the results of the two groups were normally distributed. For the intragroup evaluation, Paired Sample t-test was used for the comparison of volumetric measurements before expansion (TO) and after retention (T1) in both groups.

For the intergroup evaluation, Student's t-test was used for comparing volumetric measurements between two groups, considering numerical and percent volumetric changes. Test results are presented as mean and standard deviation in the tables. $\mathrm{P}<0.05$ value was used for the statistical significance.

To examine the error associated with digitizing and measurements, 15 images were selected randomly and all procedures (landmark identification, tracing, measuring) were repeated three weeks after the first examination, by the same orthodontist (O.O.) without knowledge of the first measurements. Intra-
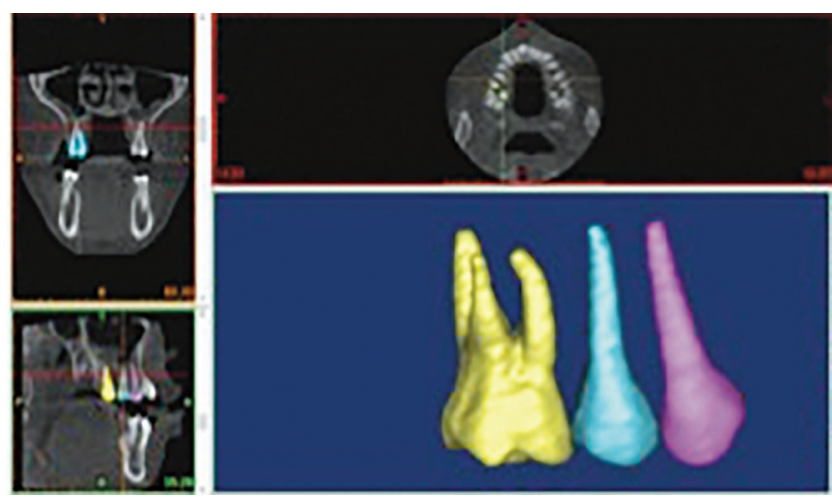

Figure 4. The volumetric measurements of the isolated teeth were made and changes occurred in the beginning and after the retention were recorded class correlation coefficients, performed to assess the reliability of the measurements, showed that the values were over 0.951 , confirming the reliability of the measurements. The results of the paired $t$-test to assess the systemic error showed that all measurements were free of systemic error $(p>0.05)$.

\section{Results}

\section{Intragroup Comparison}

The amount of expansion was measured as 7.96 $\mathrm{mm}$ in the first group and as $7.67 \mathrm{~mm}$ in the second group. The mean age was $13.4 \pm 1.2$ years in the first group and $13.2 \pm 1.3$ years in the second group. There was no significant difference between the groups in the amount of expansions and mean ages ( $p>0.05)$.

In the first group, the mean volumetric measurement was $584,021 \pm 49,009 \mathrm{~mm}^{3}$ before the expansion and $546,249 \pm 48,475 \mathrm{~mm}^{3}$ after the retention for the $1^{\text {st }}$ premolar. Mean volumetric measurement was $557,854 \pm 34,531 \mathrm{~mm}^{3}$ before the expansion and $524,472 \pm 34,777 \mathrm{~mm}^{3}$ after the retention for the $2^{\text {nd }}$ premolar. Mean volumetric measurement was $1226,584 \pm 62,003 \mathrm{~mm}^{3}$ before the expansion and $1146,932 \pm 67,541 \mathrm{~mm}^{3}$ after the retention for the $1^{\text {st }}$ molar. All these decreases were statistically significant $(p<0.05)$ (Table 2$)$.

In the second group, the mean volumetric measurement was $567,85 \pm 57,158 \mathrm{~mm}^{3}$ before the expansion and $545,568 \pm 57,187 \mathrm{~mm}^{3}$ after the retention for the $1^{\text {st }}$ premolar. Mean volumetric measurement was $540,726 \pm 52,639 \mathrm{~mm}^{3}$ before the expansion and $516,117 \pm 58,719 \mathrm{~mm}^{3}$ after the retention for the $2^{\text {nd }}$ premolar. Mean volumetric measurement was $1218,423 \pm 69,984 \mathrm{~mm}^{3}$ before the expansion and $1172,285 \pm 63,144 \mathrm{~mm}^{3}$ after the

Table 2. Results of traditional rapid maxillar expansion and bone-borne rapid maxillar expansion at T0 and T1

\begin{tabular}{|c|c|c|c|c|c|c|}
\hline \multirow{2}{*}{ Group } & \multirow{2}{*}{ Tooth } & \multicolumn{2}{|c|}{ TO $\left(\mathrm{mm}^{3}\right)$} & \multicolumn{2}{|c|}{$\mathrm{T} 1\left(\mathrm{~mm}^{3}\right)$} & \multirow{2}{*}{$\mathbf{p}$} \\
\hline & & Mean & SD & Mean & SD & \\
\hline \multirow[b]{3}{*}{ TRME appliance } & $1^{\text {st }}$ Premolar & 584.021 & 49,009 & 546,249 & 48,475 & $<0.001 * * *$ \\
\hline & $2^{\text {nd }}$ Premolar & 557,854 & 34,531 & 524,472 & 34,777 & $<0.001 * * *$ \\
\hline & $1^{\text {st }}$ Molar & $1,226,584$ & 62,003 & $1,146,932$ & 67,541 & $<0.001 * * *$ \\
\hline \multirow[b]{3}{*}{ BBRME appliance } & $1^{\text {st }}$ Premolar & 567,185 & 57,158 & 545,568 & 57,187 & $<0.001^{* * *}$ \\
\hline & $2^{\text {nd }}$ Premolar & 540,726 & 52,639 & 516,117 & 58,719 & $<0.001 * * *$ \\
\hline & $1^{\text {st }}$ Molar & $1,218,423$ & 69,984 & $1,172,285$ & 63,144 & $<0.001 * * *$ \\
\hline
\end{tabular}


retention for the $1^{\text {st }}$ molar. All these decreases were statistically significant $(p<0.05)$ (Table 2$)$.

\section{Intergroup Comparison}

The null hypothesis of our study was rejected. The mean amount of root resorption in the $1^{\text {st }}$ premolar was measured as $37,772 \pm 10,644 \mathrm{~mm}^{3}$ in the first group, and as $21,617 \pm 11,251 \mathrm{~mm}^{3}$ in the second group, which was statistically significant less than first group $(p<0.05)$ (Table 3$)$.

The mean amount of root resorption in the $2^{\text {nd }}$ premolar was measured as $33,382 \pm 11,474 \mathrm{~mm}^{3}$ in the first group, and as $24,609 \pm 15,398 \mathrm{~mm}^{3}$ in the second group, which was statistically significant less than first group $(p<0.05)$ (Table 3$)$.

The mean amount of root resorption in the $1^{\text {st }}$ molar was measured as $79,651 \pm 13,278 \mathrm{~mm}^{3}$ in the first group, and as $46,148 \pm 20,964 \mathrm{~mm}^{3}$ in the second group, which was statistically significant less than first group $(p<0.05)$ (Table 3$)$.

The percental volumetric decreased for the $1^{\text {st }}$ premolar was $6.48 \%$ in the first group and $3.82 \%$ in the second group, which was statistically significant less than first group $(p<0.05)$ (Table 4).

The percental volumetric decreased for the- $2^{\text {nd }}$ premolar was $5.98 \%$ in the first group and $4.67 \%$ in the second group, which was not statistically significant less than first group ( $p>0.05$ ) (Table 4).
The percental volumetric decreased for-the $1^{\text {st }}$ molar was $6.53 \%$ in the first group and $3.76 \%$ in the second group, which was statistically significant and less than first group $(p<0.05)$ (Table 4).

\section{Discussion}

When the orthodontic literature was reviewed, not to much study based on 3D comparison of root resorptions after using TRME and BBRME appliances was found.

According to numerous studies, the most appropriate age for the performing RME is $8-15$ years (2). The existence of open root apex may negatively influence the measurements of root resorption and may compromise the reliability of results (18). In accordance with this information, patients between 12-15 years of age were included in this study.

Bonded appliances, covering all the surfaces of posterior teeth, were designed in order to provide better vertical control. Acrylic parts extending to the occlusal surfaces of the teeth also act as bite blocks. Therefore, forces provided by the miniscrew can be transmitted directly to the suture without any obstacles $(19,20)$. Some studies claim that less root resorption occurs with usage of these appliances (21).

Table 3. Comparison of the results of traditional rapid maxillar expansion and bone-borne rapid maxillar expansion at TO and T1

\begin{tabular}{|l|l|l|l|l|l|}
\hline \multirow{2}{*}{ Tooth } & \multicolumn{2}{|c|}{ TRME (n=20) } & \multicolumn{2}{c|}{ BBRME (n=20) } & \multirow{2}{*}{} \\
\cline { 2 - 6 } & Mean & SD & Mean & SD & \\
\hline $1^{\text {st }}$ Premolar & 37,772 & 10,644 & 21,617 & 11,251 & $<0.001^{* * *}$ \\
\hline $2^{\text {nd }}$ Premolar & 33,382 & 11,474 & 24,609 & 15,398 & $0.048^{*}$ \\
\hline $1^{\text {st }}$ Molar & 79,651 & 13,278 & 46,148 & 20,964 & $<0.001 * * *$ \\
\hline
\end{tabular}

TRME: Traditional rapid maxillary expansion, BBRME: Bone-borne rapid maxillary expansion, T0: In the beginning, T1: After 3 months, SD: Standard deviation, $p<0.05$ value was used for the statistical significance, ${ }^{*} p<0.05,{ }^{* *} p<0.01,{ }^{* * *} p<0.001$

Table 4. Comparison of the results of traditional rapid maxillary expansion and bone-borne rapid maxillary expansion at $\mathrm{TO}$ and $\mathrm{T} 1$

\begin{tabular}{|c|c|c|c|c|c|}
\hline \multirow{2}{*}{ Tooth } & \multicolumn{2}{|c|}{ TRME $(n=20)$} & \multicolumn{2}{|c|}{ BBRME $(n=20)$} & \multirow{2}{*}{$\mathbf{p}$} \\
\hline & $\mathrm{mm}^{3}$ & $\%$ & $\mathrm{~mm}^{3}$ & $\%$ & \\
\hline $1^{\text {st }}$ Premolar & 37,772 & $6.68 \%$ & 21,617 & $3.82 \%$ & $<0.001^{* * *}$ \\
\hline $2^{\text {nd }}$ Premolar & 33,382 & $5.98 \%$ & 24,609 & $4.67 \%$ & 0.117 \\
\hline $1^{\text {st }}$ Molar & 79,651 & $6.53 \%$ & 46,148 & $3.76 \%$ & $<0.001^{* * *}$ \\
\hline
\end{tabular}

TRME: Traditional rapid maxillary expansion, BBRME: Bone-borne rapid maxillary expansion, T0: In the beginning, T1: After 3 months, SD: Standard deviation, $p<0.05$ value was used for the statistical significance, ${ }^{*} p<0.05,{ }^{* *} p<0.01,{ }^{* * *} p<0.001$ 
Considering this, the first group was formed using the records of the patients who were treated by full coverage traditional RME.

BBRME appliances are placed on the palatal vault. Forces transmitted to the maxilla pass nearer to the center of resistance of the maxilla in BBRME than in TRME, that's why more parallel expansion may be achieved by BBRME appliances $(7,22)$. Another advantages of BBRME are usage in hipodontia cases, usage for patients having periodontological problems, being more hygienic. However, longer and troublesome laboratory procedures and difficulty in appliance are the disadvantages of $\operatorname{BBRME}(6,23)$.

Hybrid expander constists of two miniscrews placed on the palatal bone and the acrylic part covering these screws. It was showed that 2 miniscrews could counter the forces provided by the RME appliance with this method (14). We prefer Hybrid expander in our clinic due to some advantages such as less cost, easy in practice, reduction of side effects caused by the screw, patient acceptance, no requirement of another appliance for the retention. In addition, Akin et al. (14) used acrylic raised lower essix plaque to diminish occlusal contacts and resistance. Patients who also used acrylic raised lower essix plaque during their expansion was chosen for our study.

CBCT was developed to display small areas like the maxilla in in vivo studies. Low-dose radiation and lower costs are the prominent advantages of the method $(7,10,17)$. Moreover, accurate and precise findings were attained from the maxillofacial area in some studies (24). Therefore, CBCT radiographs of the patients taken before and after the treatment were used for our study.

Bishara and Staley (2) stated in their studies that the expansion appliance should be kept in the mouth for 3-6 months for the retention and that tension occurred on the soft tissues surrounding the maxilla after RME which was a substantial level considering relapse.

The hyrax appliance was used in 18 patients in Langford and Sims (25) study. After the expansion procedure, patients' retention procedure lasted for 14-53 weeks. Then, $1^{\text {st }}$ premolars were extracted and root resorptions were observed under the electron microscope. In the study, active root resorption was observed in the first 3 months. Measurements were made on CBCT records taken 3 months after the expansion in both groups to be able to observe resorption process better.

In our study, statistically significant root resorption occurred for all the teeth in the first group. The greatest resorption occurred in the $1^{\text {st }}$ molar, followed by the $1^{\text {st }}$ premolar, and the lowest resorption occurred in the $2^{\text {nd }}$ premolar. These findings were similar to those of Dindaroğlu and Doğan (10) studies, in which root resorption was observed after bone borne RME and ranking of root resorptions of the teeth were the same as that obtained study.

Although ranking of root resorptions of the teeth was the same, as that obtained in the study of Baysal et al. (17), less root resorption was observed. However, teeth were cut from the furcation parts in that study while measuring the root resorption. So, root resorptions in the cervical parts could not be measured. The difference in the root resorption amount between the two studies may be due to this reason. The other reason of this difference may be that since $\mathrm{T} 2$ records were taken just after the expansion, the resorption process could not be completed as Baysal et al. (17) also reported.

In the second group, statistically significant root resorption occurred in all the teeth. Odenrick et al. (26) stated that root resorption was observed also on the uncovered teeth. The results gained from the uncovered teeth in our study were similar to Odenrick's findings.

Results obtained after three months of retention in Barber and Sims (9) study considering root resorption were compatible with the results of the first group in our study. However, authors claimed that the uncovered teeth were exposed to lateral movement and relaps thereafter, and that resorption occurred as a result. These findings contradicted with the results of our second group.

Langford and Sims (25) reported that severe relapse forces arised in the first 3 months after RME causing root resorption. In the second group of our study, since the teeth were uncovered, the forces provided by soft tissue tensions after the expansion were directly transmitted to teeth. The reason of observing root resorption in the second group although there was no direct force transmission to the teeth may be results of the relapse forces.

Statistically more significant resorption occurred in the first group than in the second group. In Lin et al. 
(7) study, dental and skeletal effects of tooth borne and bone borne RME appliances on the maxilla were compared. There was statictically more dental tipping for all teeth in the tooth borne group. There are many studies showing that BBRME appliances cause less dental tipping $(14,23)$. That might be the reason of less resorption observed in the second group compared to the first group in our study.

This result supports the hypothesis defended by the authors researching bone borne RME that less root resorption occurs after bone borne $\operatorname{RME}(6,13,14,27)$.

\section{Conclusion}

Statistically significant root resorption occurred in both TRME and BBRME groups. The greatest resorption occurred in the $1^{\text {st }}$ molar, followed by the $1^{\text {st }}$ premolar, and the lowest resorption occurred in the $2^{\text {nd }}$ premolar in first group.

The greatest resorption occurred in the $1^{\text {st }}$ molar, followed by the $2^{\text {nd }}$ premolar, and the lowest resorption occurred in the $1^{\text {st }}$ premolar in second group.

Percental root resorption change in the $1^{\text {st }}$ molar and for the $1^{\text {st }}$ premolar in the first group were statistically more significant than that in the second group; however no statistically difference was observed for the $2^{\text {nd }}$ premolar.

When the root resorption was compared between the groups, statistically lower significant root resorption was observed for all teeth in the BBRME group than in-the TRME group.

\section{Ethics}

Ethics Committee Approval: The study protocol was approved by the Ethics Committee of the Selçuk University Faculty of (protocol no: 2015/01, date: 08.10.2015).

Informed Consent: All patients and their parents were informed about the research and signed informed consent forms.

Peer-review: Externally peer-reviewed.

\section{Authorship Contributions}

Concept: M.A., Design: M.A., Supervision: M.A., O.Ö., Fundings: M.A., O.Ö., Materials: O.Ö., Data Collection or Processing: O.Ö., Analysis or Interpretation: M.A., Literature Search: O.Ö., Critical Review: M.A., Writing: M.A., O.Ö.

Conflict of Interest: No conflict of interest was declared by the authors.
Financial Disclosure: The authors declared that this study received no financial support.

\section{References}

1. Timms DJ. A study of basal movement with rapid maxillary expansion. Am J Orthod 1980; 77: 500-7.

2. Bishara SE, Staley RN. Maxillary expansion: clinical implications. Am J Orthod Dentofacial Orthop 1987; 91: 3-14.

3. Matsumoto $M$, Yoshii O. [A case report of the rapid expansion of the maxillary dental arch by opening the mid palatal suture]. Nihon Kyosei Shika Gakkai Zasshi 1968; 27: 166-74.

4. Yildirim M, Akin M. Comparison of root resorption after boneborne and tooth-borne rapid maxillary expansion evaluated with the use of microtomography. Am J Orthod Dentofacial Orthop 2019; 155: 182-90.

5. Sindel A, Dereci Ö, Hatipoğlu M, Özalp Ö, Dereci ON, Kocabalkan $B$, et al. Evaluation of temperature rise following the application of diode and ErCr:Ysgg lasers: an ex vivo study. Eur Oral Res 2018; 52: 131-6.

6. Winsauer H, Vlachojannis J, Winsauer C, Ludwig B, Walter A. A bone-borne appliance for rapid maxillary expansion. J Clin Orthod 2013; 47: 375-81.

7. Lin L, Ahn HW, Kim SJ, Moon SC, Kim SH, Nelson G. Tooth-borne vs bone-borne rapid maxillary expanders in late adolescence. Angle Orthod 2015; 85: 253-62.

8. Haas AJ. Palatal expansion: just the beginning of dentofacial orthopedics. Am J Orthod 1970; 57: 219-55.

9. Barber AF, Sims MR. Rapid maxillary expansion and external root resorption in man: a scanning electron microscope study. Am J Orthod 1981; 79: 630-52.

10. Dindaroğlu F, Doğan S. Evaluation and comparison of root resorption between tooth-borne and tooth-tissue borne rapid maxillary expansion appliances: A CBCT study. Angle Orthod 2016; 86: 46-52.

11. Ballanti $F$, Lione $R$, Fanucci $E$, Franchi L, Baccetti T, Cozza P. Immediate and post-retention effects of rapid maxillary expansion investigated by computed tomography in growing patients. Angle Orthod 2009; 79: 24-9.

12. Garib DG, Henriques JF, Janson G, de Freitas MR, Fernandes AY. Periodontal effects of rapid maxillary expansion with tooth-tissue-borne and tooth-borne expanders: a computed tomography evaluation. Am J Orthod Dentofacial Orthop 2006; 129: 749-58.

13. Mommaerts MY. Transpalatal distraction as a method of maxillary expansion. Br J Oral Maxillofac Surg 1999; 37: 268-72.

14. Akin M, Akgul YE, lleri Z, Basciftci FA. Three-dimensional evaluation of hybrid expander appliances: A pilot study. Angle Orthod 2016; 86: 81-6.

15. Halazonetis DJ. From 2-dimensional cephalograms to 3-dimensional computed tomography scans. Am J Orthod Dentofacial Orthop 2005; 127: 627-37.

16. Heimisdottir K, Bosshardt D, Ruf S. Can the severity of root resorption be accurately judged by means of radiographs? $A$ 
case report with histology. Am J Orthod Dentofacial Orthop 2005; 128: 106-9.

17. Baysal A, Uysal T, Veli I, Ozer T, Karadede I, Hekimoglu S. Evaluation of alveolar bone loss following rapid maxillary expansion using cone-beam computed tomography. Korean J Orthod 2013; 43: 83-95.

18. Linge L, Linge BO. Patient characteristics and treatment variables associated with apical root resorption during orthodontic treatment. Am J Orthod Dentofacial Orthop 1991; 99: 35-43.

19. Timms DJ. A study of basal movement with rapid maxillary expansion. Am J Orthod 1980; 77: 500-7.

20. Memikoglu TU, Işeri $H$. Effects of a bonded rapid maxillary expansion appliance during orthodontic treatment. Angle Orthod 1999; 69: 251-6.

21. Alpern MC, Yurosko JJ. Rapid palatal expansion in adults with and without surgery. Angle Orthod 1987; 57: 245-63.

22. Garib DG, Navarro R, Francischone CE, Oltramari PV. Rapid maxillary expansion using palatal implants. J Clin Orthod 2008; 42: $665-71$
23. Tausche E, Hansen L, Hietschold V, Lagravère MO, Harzer W. Three-dimensional evaluation of surgically assisted implant bone-borne rapid maxillary expansion: a pilot study. Am J Orthod Dentofacial Orthop 2007; 131: 92-9.

24. Suomalainen A, Vehmas T, Kortesniemi M, Robinson S, Peltola J. Accuracy of linear measurements using dental cone beam and conventional multislice computed tomography. Dentomaxillofac Radiol 2008; 37: 10-7.

25. Langford SR, Sims MR. Root surface resorption, repair, and periodontal attachment following rapid maxillary expansion in man. Am J Orthod 1982; 81: 108-15.

26. Odenrick L, Karlander EL, Pierce A, Kretschmar U. Surface resorption following two forms of rapid maxillary expansion. Eur J Orthod 1991; 13: 264-70.

27. Akın M, Erdur EA, Öztürk O. Asymmetric dental arch treatment with Forsus fatigue appliances: Long-term results. Angle Orthod 2019; 89: 688-96. 